\title{
Strengthening agriculture-nutrition linkages to improve consumption of nutrient-dense perishable foods in India - existing evidence and way forward
}

\author{
Kiruthika Selvaraj, Ankita Mondal, Bharati Kulkarni* \\ Clinical Division, National Institute of Nutrition (ICMR), Hyderabad, Telangana, India \\ (Received: 17-06-2020; Revised: 05-09-2020; Accepted: 13-09-2020; Published: 09-07-2021 \\ *Corresponding author: Bharati Kulkarni (E-mail: dr.bharatikulkarni@gmail.com)
}

\begin{abstract}
The triple burden of malnutrition in India is largely contributed by poor quality diets lacking adequate intake of nutrient dense perishable foods (NDPFs) - milk, eggs, fruits and vegetables. This is intriguing because India is one of the largest producers of NDPFs. This review examines possible reasons for this disparity. Poor post-harvest infrastructure, price volatility, unorganized supply chains, long-standing government policies favouring cereals and increasing consumer preference of convenience foods are identified as major reasons for the low intake of NDPFs. While nutrition-sensitive agriculture interventions appear promising to improve intakes of NDPF, stronger evidence is needed to scale up these interventions.
\end{abstract}

Key words: Nutrition policy, nutritional status, animal source foods, fruits and vegetables, nutrition sensitive agricultural interventions

\section{INTRODUCTION}

Despite impressive economic progress in the last few decades, nationally representative data from India show the persistent triple burden of malnutrition in the form of coexistence of undernutrition, micronutrient deficiencies and increasing prevalence of obesity and chronic diseases such as diabetes and cardiovascular diseases. For instance, the National Family Health Survey-4 (NFHS-4) showed almost 20\% prevalence of chronic energy deficiency (Body Mass Index (BMI) less than 18.5) in adults and around 38\% prevalence of stunting in children under five years of age (International Institute of Population Sciences, 2017; WHO, 2017). The high prevalence of undernutrition is unfortunately coupled with a steep increase in the proportion of overweight and obese adults in the last decade (from 10\% in 2005- 2006 to $20 \%$ in 2015 - 2016) as per the third and fourth rounds of the NFHS (International Institute for Population Sciences, 2007, International Institute of Population Sciences, 2017). The recent comprehensive national nutrition survey [CNNS(2016-18], which provided nationwide data on micronutrient deficiencies in children and adolescents (1-19 y) for the first time, shows that in many states, the prevalence of deficiencies of zinc, iron, vitamin A exceed levels indicative of severe public health problem. Moreover, one in ten school-age children and adolescents were found to be pre-diabetic and five percent of adolescents were classified as hypertensive (Ministry of Health and Family Welfare (MoHFW), 2019).

Tackling the burden of undernutrition and overnutrition, two seemingly contrasting forms of malnutrition, represents an enormous policy challenge. It has been recognized that countries need 'double duty' actions in terms of policies and interventions that can simultaneously reduce under nutrition and overnutrition (WHO, 2017).
Evidence suggests that the sub-optimal Indian diets with deficient intakes of high-quality protein, essential fatty acids and micronutrients such as iron, zinc, vitamin $\mathrm{A}$, and calcium could be an important contributor to the existing triple burden of malnutrition (Dasi et al., 2019). Dietary diversity is known to be a key indicator of nutrient adequacy in different age groups (Nithya and Bhavani, 2018; Rani et al., 2010). Achieving dietary diversity has been a major concern for policymakers as the habitual Indian diets remain monotonous, cereal dominated with very low intake of nutrient-dense foods including fruits, vegetables and animal-source foods. It is intriguing that despite decades of economic development, the diet quality remains poor. A recent study that analyzed the temporal and regional trends in Indian diets during 1993-2013 using nationally representative data highlighted that more than half of the urban and rural Indian households do not consume any meat, fish, or egg, and about a fifth of the rural households do not consume adequate fruit or milk (Tak et al., 2019). The lack of dietary diversity appears to be even more acute among young children as the recent national surveys reported that only less than $10 \%$ of the children below 5 years were consuming a minimum adequate diet (International Institute of Population Sciences, 2017; National Nutrition Monitoring Bureau, 2012).

The problem of poor dietary intake of nutritious foods is further compounded by the undesirable nutrition transition which unfolded in India post-economic liberalization in the early 1990s (Pingali et al., 2005). As a result, traditional diets are being replaced by calorie-dense convenience foods across the social strata, both in rural and urban areas (Gaiha et al., 2012). Importantly, the processed convenience foods, being cheaper with longer shelf life, are replacing the nutrientdense perishable foods (NDPFs) like meat, eggs, milk, fruit, 
and vegetables, that are perceived to be expensive compared to the convenience foods (Miller et al., 2016). Thus, for optimum nutritional outcomes, policies and programs should not only regulate processed foods but need to strengthen the food systems to enable access to healthier and affordable food options for its population.

Agricultural development programs have a great potential for strengthening food systems by improving the availability and access to diverse foods needed to address the shared drivers' of the double burden of malnutrition (WHO, 2017). Over the past few decades, Indian agricultural programs have managed to achieve important successes in enhancing the production and availability of diverse foods. Following the success of the green revolution initiated in the mid-1960s that helped achieve self-sufficiency in cereal production, India focused on 'rainbow revolution' to improve production of other essential food groups which included white revolution (for milk), yellow revolution (for oilseeds), pink and blue revolution (for meat and fisheries), silver revolution (for eggs), and golden revolution (for horticultural crops, particularly fruit and vegetables) (Larson et al., 2004; Srivastava et al., 2016). With the enhanced production stimulated by these initiatives, India is now recognized as one of the largest producers of milk, eggs, fruits and vegetables. It is, therefore, intriguing that for a large section of the population, the dietary intakes of these nutritious foods are still much lower than recommended levels as indicated by the national surveys (Department of Animal Husbandry, 2017; International Institute of Population Sciences, 2017; Ministry of Agriculture \& Farmers' Welfare, 2018; National Dairy Development Board, 2017; National Nutrition Monitoring Bureau, 2012).

At a crucial time of nutrition transition, it is important to explore the possible reasons for the low consumption of the NDPFs, both from plant and animal sources, and explore ways to promote healthy dietary patterns for achieving the desired nutrition outcomes. In this article, we examine the disparity between availability and reported intakes of NDPFs (fruits, vegetables, meat, eggs, milk) and discuss the existing evidence on the possible reasons for this disconnect. We also reviewed the agricultural interventions that have been attempted in India to improve the consumption of these foods and discuss the way forward.

\section{METHODS}

\section{Assessment of the disparity between availability and consumption of NDPFs}

We obtained the data on per capita availability of different foods from relevant Indian government sites including the National Dairy Development Board (for milk), National Horticulture Board (fruits and vegetables), Department of Animal Husbandry, Dairying and Fisheries (for egg and meat) (Department of Animal Husbandry, 2017; Ministry of Agriculture \& Farmers' Welfare, 2018; National Dairy
Development Board, 2017). The consumption data for NDPFs in India was obtained from the NNMB (2011-12) survey as it provides precise data on dietary intake using quantitative methods (National Nutrition Monitoring Bureau, 2012). The availability and consumption data for NDPFs was compared to the recommended intakes as per the national dietary guidelines (National Institute of Nutrition, 2010) (Figure 1).

\section{Assessment of the possible reasons for the disparity}

To understand the possible reasons for the disparity between availability and consumption of NDPFs, we undertook a comprehensive review of the relevant evidence through a systematic search of both peer-reviewed and grey literature on Google Scholar. The search terms included "dietary intake", "dietary diversity", "nutrient adequacy", "food system*”, "production", "availabl*”, "price", "purchase", "market", "food environment" and "food choice" in combination with the food groups of interest (milk, meat, egg, fish, fruits and vegetables). We also conducted separate hand-searches and included papers from citation lists. All references were entered into Endnote and duplicates were removed. Overall, 218 relevant publications were identified and reviewed (Figure 2).

\section{Review of interventions promoting availability and consumption of NDPFs}

We conducted a systematic search of agricultural interventions conducted in India with an objective of

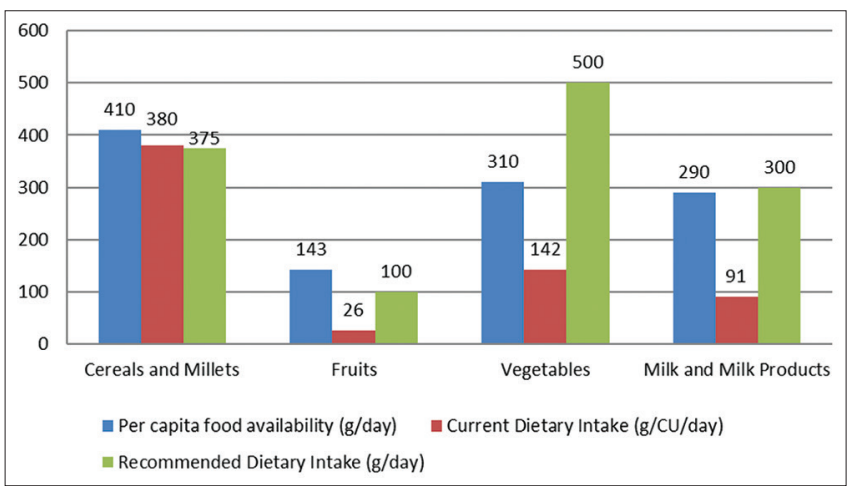

Figure 1: Availability, current dietary intake, and recommended dietary intake of nutrient-dense perishable foods (NDPFs) compared to cereals and millets

Vegetables also include roots and tubers

Sources: Per capita food availability for year 2011-12: Cereals and Millets-Department of Agriculture, Cooperation \& Farmers Welfare, 2017; Fruits, Vegetables-Department of Agriculture, Cooperation \& Farmers' Welfare, 2018; Milk-National Dairy Development Board

Current dietary intakes are expressed per CU (Consumption Unit) corresponding to the calorie consumption of an average adult man, weighing $60 \mathrm{~kg}$, doing sedentary type of work (National Nutrition Monitoring Bureau, 2012).

Recommended Dietary Intake: Indian Dietary Guidelines, Indian Council of Medical Research, 2010 

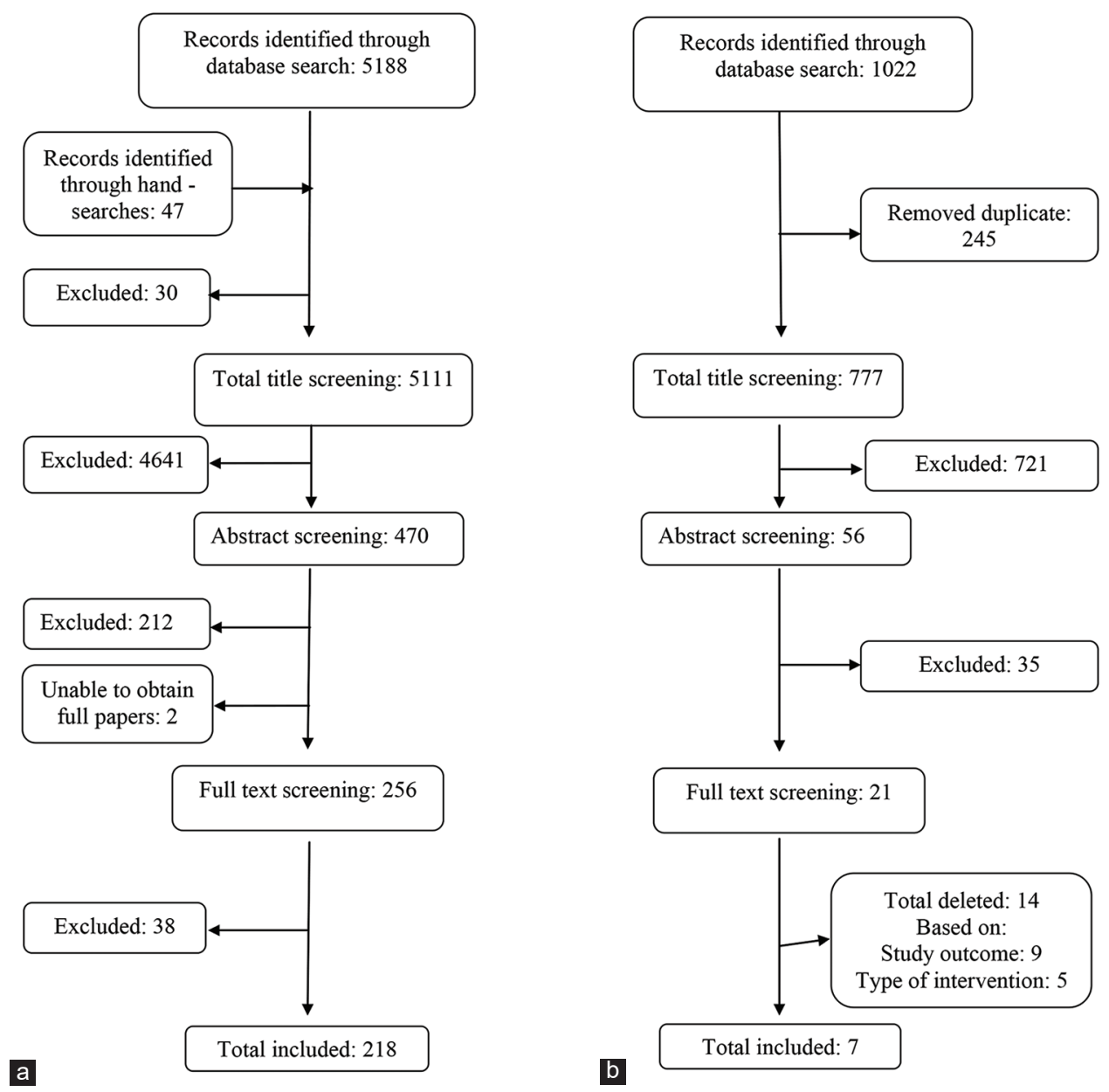

Figure 2: Flowchart of the screening process for literature review, a) Literature review to understand the reasons for the disparity between availability and consumption of NDPFs. b) Literature review on the interventions promoting availability and consumption of NDPFs

enhancing access, availability, affordability, and consumption of NDPFs. We searched the major databases including Pub Med, Google-Scholar, Proquest and some non-indexed Indian journals. We also screened the Krishikosh, which is a digital repository of research conducted by agricultural research institutions and agricultural universities in India (Indian Council of Agriculture Research-Indian Agricultural Research Institute, 2017). The key search terms included "food system", "agricult*, "nutri*”, "kitchen garden", "homestead food production", "home garden", "backyard garden", "nutrition garden", "backyard poultry", "market" "access", "availability", "affordability", "produc", "intake”, "dietary diversity", "nutri*intake", "interventions", along with any of the following terms: India, horticulture, fruit and vegetables, milk, dairy, egg, poultry, animal husbandry, aquaculture in combination.

We excluded studies with a major focus on other food groups such as cereals, millets and pulses and those which were conducted to assess the impact of interventions on agricultural or economic outcomes, studies conducted outside India, non-peer reviewed articles, grey literature and review articles (Fig.2).

\section{Review of large-scale agricultural interventions}

Additionally, we reviewed agricultural interventions implemented on a larger scale by government departments or non-government organizations that have the potential to improve dietary intake of NDPFs, but systematic impact evaluation of these programs is not available. This review, conducted for triangulating the information from the literature searches described in previous sections, was illustrative rather than exhaustive.

\section{RESULTS}

\section{The disparity between availability and consumption of NDPFs}

Our findings show that the consumption matches the requirement only in case of cereals and millets, whereas a wide gap exists in case of the NDPFs including vegetables, fruits and milk. Comparable data on fish, eggs and meat are not available; but reported dietary intakes of these foods are very low (15 g/ consumption unit (CU)/day of fish and an aggregate of $9 \mathrm{~g} / \mathrm{CU} /$ day of all types of meat and eggs (National Nutrition Monitoring 
Bureau, 2012). This disconnect between per capita availability and reported intake of the NDPFs needs closer examination.

\section{Milk}

With the growing demand for milk consequent to increased incomes and development of milk co-operatives, milk production in India increased substantially in the past few decades. India is currently the largest producer of milk in the world, with an average annual production increase of 6.4\% during years 2014-2018. However, milk consumption, especially in rural areas, is not on par with production and availability. Despite the per capita availability of $290 \mathrm{~g} /$ day in the year 2011-12, the actual intake of milk and milk products in rural India was only $91 \mathrm{~g} / \mathrm{CU} /$ day (Fig. 1), where almost $57 \%$ of the participants consumed less than $50 \%$ of their daily recommendation of dairy foods $(300 \mathrm{ml} / \mathrm{CU} /$ day)(National Dairy Development Board, 2017; National Institute of Nutrition, 2010; National Nutrition Monitoring Bureau, 2012).

\section{Other animal source foods}

Available data on availability and consumption of meat, fish, and eggs are sparse and surveys on dietary intakes often report combined intake of these food groups. The per capita availability of eggs has almost doubled in the past two decades: from 36 eggs per annum in 2000-2001 to 69 eggs per annum in 2016-2017 (Department of Animal Husbandry, 2017). The total meat production has also increased from 1.9 million tonnes in 2001-02 to 5.9 million tonnes in 2012-13. However, consumption of these animal source foods has been very low in rural areas of India with a mean intake of $15 \mathrm{~g} / \mathrm{CU} /$ day of fish and a combined intake of $9 \mathrm{~g} / \mathrm{CU} /$ day of all kinds of meat and eggs (National Nutrition Monitoring Bureau, 2012).

\section{Fruits and vegetables}

India is one of the largest producers of horticulture, growing nearly $11 \%$ of the world's vegetables and $15 \%$ of all fruits. On average, the per capita availability estimates (g/day) of fruits and vegetables are 150 and 310 respectively, but the actual consumption is only $63 \mathrm{~g} / \mathrm{CU} /$ day for vegetables and $26 \mathrm{~g} / \mathrm{CU} /$ day for fruits (Ministry of Agriculture \& Farmers' Welfare, 2018; National Nutrition Monitoring Bureau, 2012)(Fig. 1).

\section{Possible reasons for the disparity}

Synthesis of the evidence from selected studies based on our search criteria suggests that the major reasons for the disconnect between production and consumption are related to constraints at production level, market level as well as the household level as described below.

\section{Inadequate post-harvest handling and poor supply chains}

One of the major drawbacks in the Indian agriculture sector is inadequate infrastructure and poor facilities for safe storage and transport of NDPFs resulting in enormous food wastage. The sub-optimal supply chains with several intermediaries, manual handling, and inefficient cold chain systems distant from the farms result in $30-40 \%$ loss of the produce, particularly fruits and vegetables (Maheshwar and Chanakwa, 2006; Negi and Anand, 2016b). It is reported that only 10 to $11 \%$ of the fruits and vegetables produced in India use cold storage and that the storage capacity needs to be increased by 40 percent in order to avoid wastage (Rais et al., 2019). Post-harvest losses reduce the availability and increase the unit price rendering them unaffordable to the poorer sections of the population (Murthy et al., 2009). Moreover, a large share of a farmer's realizable value is lost due to supply chain mishandling, related losses and commission to the intermediaries (Sachdeva et al., 2013). Inadequate interlinkages between the farmers, processing units and the market is identified as a critical factor responsible for post-harvest losses (Gardas, et al., 2018; Negi and Anand, 2016a).

Furthermore, although the country level production of NDPFs like fruits, vegetables, eggs is high, there are substantial inter-state and regional differences. Urban - rural differences in consumption are also stark. It has been reported that the urban population consumes much of the eggs produced while the rural and tribal areas have limited access to the eggs and meat produced from the industrial sources (Panda and Samal, 2016; Saran et al., 2005). Inefficient transport from producing zones to non-producing zones results in large food wastages and reduced availability of NDPFs, especially fruits and vegetables (Negi and Anand, 2015).

Processing and value addition activities, that help diversify the food basket by improving market availability, are also low in India; less than 3\% of fruits and vegetables are processed, with huge losses in the value chain between the farm gate and the consumer. The small and medium enterprises can benefit from the marketing opportunities of these perishable food items along the value chain while making them available in the local market. However, several drawbacks that set back these opportunities have been identified, including poor quality of input supplies, limited access to technology and technical expertise, low production efficiency as well as lack of knowledge (Rais et al., 2019)

\section{Policies prioritizing cereal grains}

Emerging from the need to ensure food security for the population on the background of widespread hunger and famines in the post-independence era, Indian food policies continue to focus on attaining calorie adequacy (Kesavan and Swaminathan, 2012). With the successful Green Revolution in the mid 1960s and the resultant surplus grain production, the government procures the cereal grains at a Minimum Support Price (MSP) to support remuneration to the producers, and distributes them to the consumers through Public Distribution System (PDS), thus ensuring food security. However, the over-emphasis on cereal grains has resulted in restricted diversification of the food production system in India as farmers, predominantly smallholders (owning $<2$ hectares 
of land), prefer growing staple grains over NDPFs, thereby reducing local availability of these nutritionally important foods (Pingali and Sunder, 2017). Moreover, the availability of cheaper cereal grains may also result in reduced diet quality as studies have shown that with access to PDS, households tend to substitute nutrient-rich foods with cereal grains (NITI Aayog, 2016).

\section{Weak market linkages affecting access to NDPFs}

In India, while the market infrastructure is developed and organized for food grains, the markets for NDPFs are fragmented (Chittora et al., 2017; Nandakumar et al., 2010). Formal agricultural market infrastructure is positively correlated with the consumption of fruits and vegetables (Choudhury et al., 2018) while similar studies from India on animal source foods are not available. Irregular markets is a serious concern for the consumers, who are highly dependent on markets for food purchases as almost $68-74 \%$ of food is purchased by households to supplement own production (Narayanan, 2019). Similar to other low and middle income countries (LMICs), the poor market infrastructure and weak supply chains cannot handle wastage prone NDPFs, reducing their accessibility and affordability for consumers (High Level Panel of Experts on Food Security and Nutrition, 2017). Studies have revealed that improving market access for NDPF producers may generate competition among the farmers to produce diverse foods, thereby enhancing the availability and consumption of NDPFs (Chatterjee and Kapur, 2017).

\section{High and fluctuating prices}

Affordability is the most important determinant for the population level consumption of NDPFs especially among the rural poor (Dangour et al., 2013; Kehoe et al., 2019; Meenakshi, 2016; Ohlan, 2016; Shetty, 2002). Foods such as fruits, vegetables, milk, poultry and meat are usually perceived to be "costly" foods that are eaten on special occasions or are limited during adverse financial conditions in LMICs owing to their comparatively higher cost, poorer access and availability (Aurino and Morrow, 2018; Morris et al., 2018; Surendran et al., 2020). Using nationallevel food expenditure and income data, a recent study showed that the cost required to meet the recommended dietary intake is unaffordable for more than $45 \%$ of the rural households (Raghunathan et al., 2020). The study revealed that, to meet dietary recommendations, the 'per serving' cost of nutritionally significant foods like fruits and dairy is the highest, whereas the cost of oils, fats and starchy staples is the lowest. Another large multi-country study assessing availability and affordability of fruits and vegetables in LMICs also estimated that the per day cost of recommended three servings of vegetables and two servings of fruits would amount to $18 \%$ of the household income (Miller et al., 2016). The consumption of animal source NDPFs is influenced by the prices of other food groups as shown by a study by Rampal, where a shift towards consumption of animal source
NDPFs was observed when the price of pulses increased (Rampal, 2018).

High fluctuations in prices of NDPFs could be attributed to seasonal supply (fruits and vegetables), irregular demand, lack of storage infrastructure as well as the impact of shocks like drought and flood (Sekhar et al., 2017). Studies have also noted other challenges such as lack of price monitoring and policy level challenges such as lack of inter-ministerial coordination, lack of understanding of the nutritional implications of agriculture policies, prioritization of nonnutritious foods, policy investment in a more calorie-oriented approach to nutrition and a gap between policy-making and implementation (Choudhury et al., 2018; Khandelwal et al., 2019; Minocha et al., 2019; Raghunathan et al., 2020; Thow et al., 2016; van den Bold et al., 2015).

\section{Changing consumer preferences}

Studies have reiterated that while the purchase of NDPFs depends on local availability, relative price and family income, consumption of NDPF (particularly animal source NDPFs such as meat, fish and egg) is further challenged by regional, religious and cultural preferences and household level factors such as caste, family size as well as the influence of crucial decision makers in the family (husband, mother-in-law) on food purchases and consumption (Alae-Carew et al., 2019; Bailey et al., 2018; Choudhury et al., 2018; Devi et al., 2014).

In addition, consumer preference for NDPFs is frequently influenced by media-driven food scares (such as adulteration of milk, pesticide residues in vegetables, artificial ripening of fruits, heavy metal toxicity in seafood, steroid injected poultry birds to increase the weight of meat etc.) that lead to lower demand thereby consumption of the particular NDPF (Gavaravarapu, 2019; Krishna and Qaim, 2008; UmaliDeininger and Sur, 2007).

Consumer preferences are also determined by women's time availability. With changing work environments, high workload along with poor childcare support, women are more likely to choose convenience foods over NDPFs (Chaturvedi et al., 2016). Convenience in terms of proximity to store, foods that need lesser cooking time, minimal cleaning and processing are preferred by women (Ali et al., 2010; Bailey et al., 2018; Choudhary, 2014; Dhir and Singla, 2019; Pendse and Patil, 2016). When marketed as low unit packs, the commercially processed foods tend to be cheaper and affordable along with additional benefit of convenience and therefore, displace the demand for "costly" items such as fruit, milk, and poultry (Dubey and Patel, 2004).

Marketing strategies and advertisements of commercially packaged foods further enhance their consumer demand, especially among children and adolescents. A recent review of processed food intake among children less than 24 months of age in LMICs showed that $13 \%$ to $38 \%$ of their total dietary energy is obtained from salt and sugar-rich processed foods 
(Pries et al., 2019). Surprisingly even in rural India, the consumption of convenience foods like chips, chocolates is high (Gupta et al., 2016). The rising consumption of processed snacks might be attributed to policies promoting food processing which enhanced the availability and affordability of processed foods (Thow et al., 2016).

Thus, the resulting food environment with a heavy presence of processed commercial foods and scarce availability and reduced affordability of NDPFs could be the primary reason underlying the unhealthy diets and triple burden of malnutrition in transitioning societies like India.

\section{Review of Interventions Promoting Availability and Consumption of NDPFs}

Nutrition-sensitive agriculture gained momentum in the last decade with publication of a wide range of reviews explicitly assessing the agriculture and nutrition linkages in LMICs, particularly in South Asia (Gillespie et al., 2012; Girard et al., 2012; Kadiyala et al., 2014; Masset et al., 2012; Ruel et al., 2018; Shankar et al., 2019). However, evidence based on studies evaluating the impact of agricultural interventions on nutritional outcomes has been meagre, especially in India (Berti et al., 2004; Bird et al., 2019; Pandey et al., 2016).

We found seven studies that met the inclusion criteria for this review. These studies mainly assessed the impact of two interventions on consumption of NDPFs with or without other nutrition outcomes: homestead food production $(n=6)$ and usage of information and communication technology (ICT) for agricultural input and market linkages $(n=1)$. Majority of the studies (Table 1) involved a combination of interventions (Birdi and Shah, 2016; Chakravarty, 2000; Dubé et al., 2020; Murty et al., 2016; Murty et al., 2013; Pradhan et al., 2018; Vijayaraghavan et al., 1997). The main strategies included distribution of seeds and saplings of fruits and vegetables (4 studies, 1 study included Vitamin A rich crops exclusively), provision of nutrition education (6 studies, 1 study specifically focussed on Vitamin A), education on green methods of farming (1 study) and introduction of high yield variety of poultry birds ( 2 studies). The interventions were conducted at the household level (6 studies), and one study focussed on pregnant women and mothers of young children (Murty et al., 2016). Most of the studies assessed the impact on diets, especially consumption of fruits, vegetables (5 studies, 1 study exclusively on Vitamin A rich crops) and eggs (3 studies). Six of these studies were before-after studies (did not have a control arm) while one was a quasiexperimental study (Dubé et al., 2020). While all the seven studies assessed indicators of dietary intake, changes in nutritional knowledge, attitudes and practices (Chakravarty, 2000; Murty et al., 2016; Vijayaraghavan et al., 1997), two studies also assessed clinical signs of vitamin A deficiency (Chakravarty, 2000; Vijayaraghavan et al., 1997). Only one study assessed anthropometric measures of nutritional status (Murty et al., 2016). Majority of the studies were of medium and low quality (before-after and quasi-experimental studies without a control arm) similar to other published studies on complex interventions (Kadiyala et al., 2014; Pandey et al., 2016). Importantly, almost all studies demonstrated benefit in terms of enhanced dietary intake of target foods (fruits, vegetables and eggs) (Bird et al., 2019; Pandey et al., 2016; Ruel et al., 2018).

In the quasi-experimental study using ICT based intervention, consumption of fruits and vegetables improved in the rural households while no benefit was observed in the urban site (Dubé et al., 2020). In before-after studies that promoted home nutrition garden (HNG) and backyard poultry (BYP), an increased consumption of fruits, vegetables and eggs was observed (Birdi and Shah, 2016; Chakravarty, 2000; Dubé et al., 2020; Murty et al., 2013; Pradhan et al., 2018; Vijayaraghavan et al., 1997). However, due tot lack of a control arm in the intervention, the results need to be interpreted with caution. A study that promoted both HNG and BYP along with nutrition education over a period of three years also reported reduction in the prevalence of underweight among children aged 6-24 months (Murty et al., 2016). Out of the two studies that assessed the impact of HNG on Vitamin A deficiency (VAD) among children, one reported reduction in clinical symptoms of VAD (Chakravarty, 2000) while the other study did not observe similar benefit (Vijayaraghavan et al., 1997). The studies have also highlighted the local constraints and need for future studies to address local demand by designing contextually appropriate interventions.

\section{Large Scale Agricultural Interventions with Potential Nutrition Benefit}

Although the above small-scale studies have shown nutritional benefits, there are challenges in scaling up these interventions. Moreover, regional differences such as diverse food patterns and distinct regional differences including access to water, agro-climatic conditions as well as factors such as cultural perceptions regarding food make it difficult to generalize the findings of these studies.

Over the past decade, various government, and nongovernment organizations (NGOs) have implemented different interventions to improve the availability and supply of NDPFs. Moreover, the recently launched POSHAN Abhiyaan (National Nutrition Mission) has set targets for improving nutrition outcomes in a time bound manner with an emphasis on improved inter-sectoral convergence, especially strengthening agriculture-nutrition linkages (NITI Aayog, 2019). However, systematic impact evaluation of these initiatives, although needed, has not been reported.

A few notable examples that could have a positive impact on improving population level access and consumption of NDPFs include integrated models such as Agri-Nutri(A2N) smart village model in Uttar Pradesh and Haryana, and the "Narva (improve watershed management), Garwa (livestock), Ghurwa (composting and generating biogas) aur Baadi (gardening at household level)" implemented by 
Table 1: Summary of interventions selected for the review

\begin{tabular}{|c|c|c|c|c|c|}
\hline Sl no. & $\begin{array}{l}\text { Author, year, } \\
\text { study location }\end{array}$ & Intervention & $\begin{array}{l}\text { Study design, } \\
\text { Sample size, } \\
\text { duration }\end{array}$ & Outcome Measure & Major Findings \\
\hline 1. & $\begin{array}{l}\text { Dube et al., 2019, } \\
\text { Odisha }\end{array}$ & $\begin{array}{l}\text { - Agricultural } \\
\text { input and market } \\
\text { linkage: Provision of } \\
\text { agricultural knowledge } \\
\text { and market linkage }\end{array}$ & $\begin{array}{l}\text { - Quasi- } \\
\text { experimental } \\
\text { - Rural study site: } \\
360 \text { households } \\
\text { - Urban study site: } \\
174 \text { households }\end{array}$ & $\begin{array}{l}\text { - Consumption of fruits and } \\
\text { vegetables }\end{array}$ & $\begin{array}{l}\text { - Rural site: Intervention group } \\
\text { had increase in fruit and } \\
\text { vegetable consumption by } 0.30 \\
\text { serving. } \\
\text { - Urban site: No difference } \\
\text { observed in the consumption of } \\
\text { fruits and vegetables }\end{array}$ \\
\hline 2. & $\begin{array}{l}\text { Pradhan } \\
\text { et al., 2018, } \\
\text { Odisha and } \\
\text { Maharashtra }\end{array}$ & $\begin{array}{l}\text { - } \mathrm{HNG}^{1} \text { : Distribution of } \\
\text { seed kits and saplings of } \\
\text { fruits and vegetables } \\
\text { - Nutrition Education }\end{array}$ & $\begin{array}{l}\text { - Before-after } \\
\text { - } 2 \text { years } \\
\text { - Maharashtra:556 } \\
\text { households } \\
\text { - Odisha: } 658 \\
\text { households }\end{array}$ & $\begin{array}{l}\text { - Consumption of fruits and } \\
\text { vegetables } \\
\text { - Variety and quantity of fruits } \\
\text { and vegetables produced }\end{array}$ & $\begin{array}{l}\text { - Increase in monthly per capita } \\
\text { consumption (mean) of green } \\
\text { leafy vegetables (from } 1.2 \mathrm{~kg} \\
\text { to } 3.4 \mathrm{~kg} \text { ), other vegetables } \\
(3.1 \mathrm{~kg} \text { to } 6.6 \mathrm{~kg} \text { ), roots and } \\
\text { tubers }(2.5 \mathrm{~kg} \text { to } 2.9 \mathrm{~kg} \text { ) and } \\
\text { fruits }(2.3 \mathrm{~kg} \text { to } 3.3 \mathrm{~kg} \text { ). } \\
\text { - Increased frequency of } \\
\text { consumption of green leafy } \\
\text { vegetables (from once a week to } \\
2-3 \text { time per week) }\end{array}$ \\
\hline 3. & $\begin{array}{l}\text { Murty } \\
\text { et al., 2016, } \\
\text { Telangana }\end{array}$ & $\begin{array}{l}\text { - HNG: Distribution of } \\
\text { seeds and saplings of } \\
\text { fruits and vegetable } \\
\text { - BYP²: promotion of } \\
\text { high egg-yielding } \\
\text { variety of poultry } \\
\text { - Health and Nutrition } \\
\text { Education }\end{array}$ & $\begin{array}{l}\text { - Before-after } \\
\text { - } 12000 \text { pregnant } \\
\text { women and } \\
\text { mothers of young } \\
\text { children } \\
\text {-3 years }\end{array}$ & $\begin{array}{l}\text { - Dietary intakes } \\
\text { - Change in knowledge, } \\
\text { attitude, practice regarding } \\
\text { health and nutrition } \\
\text { - Anthropometric indicators of } \\
\text { child nutrition }\end{array}$ & $\begin{array}{l}\text { - Increase in quantity and } \\
\text { frequency of eggs consumption } \\
\text { - Significant reduction in } \\
\text { prevalence of underweight } \\
\text { among children (6-24 months) } \\
\text { [41.5\% to } 20.2 \%]\end{array}$ \\
\hline 4. & $\begin{array}{l}\text { Birdi and } \\
\text { Shah, 2015, } \\
\text { Maharashtra }\end{array}$ & $\begin{array}{l}\text { - HNG: Distribution of } \\
\text { seeds and saplings of } \\
\text { fruits and vegetables to } \\
\text { household's nutrition } \\
\text { education }\end{array}$ & $\begin{array}{l}\text { - Before-after } \\
\text { - } 2 \text { years } \\
\text { - } 396 \text { households }\end{array}$ & - Dietary intakes & $\begin{array}{l}\text { - Increased frequency of intake } \\
\text { of green leafy vegetables, fruits, } \\
\text { roots, other vegetables and } \\
\text { eggs. }\end{array}$ \\
\hline 5. & $\begin{array}{l}\text { Murty et al., 2011, } \\
\text { Telangana }\end{array}$ & $\begin{array}{l}\text { BYP: Promotion of } \\
\text { high egg-yielding } \\
\text { varieties of poultry } \\
\text { - Training on BYP }\end{array}$ & $\begin{array}{l}\text { - Before-after } \\
\text { - } 199 \text { households ( } 2 \\
\text { locations) } 3 \text { years }\end{array}$ & - Consumption of eggs & $\begin{array}{l}\text { - Increase in frequency of eggs } \\
\text { consumed each week [1.37 to } \\
2.2] \\
\text { - Increase in number of eggs } \\
\text { consumed per capita per week } \\
\text { [0.7 to } 2.43]\end{array}$ \\
\hline 6. & $\begin{array}{l}\text { Chakravarty, } \\
\text { 2000, West Bengal }\end{array}$ & $\begin{array}{l}\text { - HNG: Provision } \\
\text { of seeds and other } \\
\text { support. } \\
\text { - Nutrition education } \\
\text { with a focus on } \\
\text { Vitamin A rich fruits } \\
\text { and vegetables. }\end{array}$ & $\begin{array}{l}\text { - Before-after } \\
\text { - } 1500 \text { households }\end{array}$ & $\begin{array}{l}\text { - Frequency of consumption } \\
\text { of green leafy and other } \\
\text { vegetables } \\
\text { - Economic benefit through } \\
\text { sale of fruits and vegetables } \\
\text { - Prevalence of signs and } \\
\text { symptoms of Vitamin A } \\
\text { deficiency } \\
\text { - Change in knowledge, } \\
\text { attitude and practice related } \\
\text { to Vit A deficiency and } \\
\text { importance of fruits and } \\
\text { vegetables in daily diets. }\end{array}$ & $\begin{array}{l}\text { - Consumption of carotene rich } \\
\text { fruits increased by } 7.5 \mathrm{~g} / \mathrm{day} / \\
\text { average consumption unit } \\
\text { (ACU) } \\
\text { - Reduction in conjunctival } \\
\text { xerosis ( } 6.4 \% \text { to } 3.5 \%) \text {, Bitot's } \\
\text { spot }(2.8 \% \text { to } 0.8 \%) \text { and night } \\
\text { blindness ( } 15.3 \% \text { to } 4.7 \%) \text {. }\end{array}$ \\
\hline 7. & $\begin{array}{l}\text { Vijayaragavan } \\
\text { et al., 1997, } \\
\text { Telangana }\end{array}$ & $\begin{array}{l}\text { HNG: Distribution of } \\
\text { seeds and seedlings } \\
\text { of carotene-rich fruits } \\
\text { and vegetables to } \\
\text { households Nutrition } \\
\text { education with a } \\
\text { focus on Vitamin A } \\
\text { deficiency }\end{array}$ & $\begin{array}{l}\text { - Before-after } \\
\text { - } 3 \text { years } \\
\text { - } 3585 \text { households }\end{array}$ & $\begin{array}{l}\text { - Consumption of } \beta \text { carotene- } \\
\text { rich foods among pre-school } \\
\text { children } \\
\text { - Change in knowledge, } \\
\text { attitude and practice related } \\
\text { to Vitamin A deficiency and } \\
\text { importance of fruits and } \\
\text { vegetables in daily diets. }\end{array}$ & $\begin{array}{l}\text { - Increase in total daily intake } \\
\text { of } \beta \text { carotene through foods } \\
\text { (from } 632 \mu \mathrm{g} \text { to } 1307 \mu \mathrm{g} \text { ) } \\
\text { - Increase (50\%) in frequency of } \\
\text { consumption of carotene-rich } \\
\text { foods compared to baseline } \\
\text { (more than once a week) }\end{array}$ \\
\hline
\end{tabular}

1 HNG: Home nutrition garden

2 BYP: Backyard poultry 
the Chhattisgarh government (Government of Chattisgarh, 2019; Sangeetha, 2018). Apart from these, various integrated farming models (Bhaskar et al., 2017; Poonam et al., 2018) and schemes promoting nutrition gardens (poshanvatikas) implemented in many states such as Bihar, Chhattisgarh, Odisha, Jharkhand, Madhya Pradesh etc are likely to improve availability and access to NDPFs (NITI Aayog, 2019).

The government schemes by animal husbandry departments for promoting livestock and poultry development in different states also offer an important opportunity for increasing local availability and access to animal source NDPFs. For example, the National dairy plan (phase I) funds for improving productivity of milch animals through production of high genetic merit (HGM) cattle and buffalo bulls, improving tnutrition of milch animals etc. and village based milk procurement systems by setting up the infrastructure and testing facilities. Similarly, the National Live Stock Mission focuses on providing livestock insurance in various states with special schemes for some states such as a scheme for developing piggery in North Eastern States (National Dairy Development Board, 2019).

Apart from the schemes focusing on enhanced production of NDPFs, interventions to strengthen supply chains are also likely to have beneficial impact on consumption. For example, the farmers' markets enabling farmers to directly sell their produce to the consumers surpassing the intermediaries and the 'banana train' that enabled transporting horticultural crops (banana) at a low transportation cost through a train with built-in ventilated and insulated containers (Krishna et al., 2019; National Horticulture Board, 2012). Digital technology based interventions like e-Kutir implemented by non-governmental organizations are also promising for improving the market availability of NDPF (Jha et al., 2016).

Majority of the above interventions, however, appear to be a missed opportunity for improving nutrition outcomes due to the sole focus on income generation without due consideration to nutrition objectives. Many programs thus choose target foods based on their economic value rather than nutritional significance. Moreover, insufficient gap analysis and documentation of the impact of successfully implemented studies limit scalability of these initiatives (Leroy et al., 2016).

\section{DISCUSSION}

The disparity between production, availability, and consumption of NDPFs in India is intriguing and our review identified a number of constraints that hinder the availability and consumption of NDPFs and thereby contributing to unhealthy dietary patterns and triple burden of malnutrition. Small scale studies implementing agricultural interventions coupled with nutrition education have shown promising results in terms of improved dietary intakes of NDPFs. However, implementing such interventions on scale, in a sustainable manner, needs strengthening food systems by addressing the production and supply chain constraints. Moreover, these efforts need to be coupled with consumer behavior change interventions in order to have the intended benefit.

Our review suggests that strengthening local markets for NDPFs is crucial as expanding such avenues would encourage their production and availability (Chatterjee and Kapur, 2017). Strengthening supply chains needs to improve infrastructure for storage and transportation in order to minimize postharvest losses and ensure regular supply and local availability. This would require improved but accessible technological support. Digital technological innovations could be exploited for improving market linkages for farmers.

Another major barrier restricting the consumption of NDPFs, especially in vulnerable population groups is their high and volatile prices. Policy interventions for regulating prices are, therefore, crucial. In addition, policy support is needed in terms of inclusion of NDPFs in government programs such as the Integrated Child Development Services (ICDS) program, Mid day meal (MDM), Public Distribution System and other social protection schemes that have historically focused on providing staple grains (Aurino and Morrow, 2018; Thow et al., 2016).

These interventions would not succeed without efforts for creating consumer awareness on the importance of NDPFs, especially for nutritionally vulnerable population groups like women and children. Generating consumer demand through improved value chains is important for ensuring supply as well as consumption. Experiences from some successful examples such as branding of eggs and milk by National Egg Coordination Committee (NECC) and dairy co-operatives (like AMUL), would be useful in this regard (Gunasekaran and Vikkraman, 2016; Parasar and Bhavani, 2016). Women, being the key decision makers regarding household diets, need to be at the centre stage of interventions aimed at improving nutritional outcomes (Rukmani et al., 2019). Potentially sustainable initiatives, therefore, need to empower women with knowledge and technical support (Poonam et al., 2018).

Our review shows that promising household level interventions such as home nutrition gardens (for fruit and vegetables) alone or in combination with animal and poultry rearing, could enhance availability, access, and consumption of the NDPFs with minimum external support. However, without adequate nutrition education, the associated economic benefits would receive priority, jeopardizing the nutritional outcomes.

It is important to acknowledge that the existing evidence is based on complex multi-component interventions (e.g. agriculture interventions along with nutrition and behaviour change communication) and it is difficult to tease out the effect of the individual interventions. Moreover, generalizability of these interventions is not known, and large-scale interventions implemented by government and other public agencies have not undergone rigorous impact evaluation or monitoring. Strengthening research in this area is crucial for guiding future interventions and policies. 
Finally, a paradigm shift in agricultural policy is needed with an unwavering focus on nutritional outcomes. The neglect of nutritional objectives in agricultural programs means a lost opportunity to impact diets and nutrition through these interventions. The initiatives, particularly by the government, must be more nutrition-sensitive and importantly dynamic and capable of adapting to changing nutrition and climate needs.

\section{Disclosure statement}

The authors declare no conflict of interests

\section{ACKNOWLEDGEMENTS}

The authors acknowledge the support of the Indian Council of Medical Research for providing fellowship to KS and AM.

\section{REFERENCES}

Alae-Carew, C., Bird, F.A., Choudhury, S., Harris, F., Aleksandrowicz, L., Milner, J., Joy, E., Agrawal, S., Dangour, A., \& Green. R. (2019). Future diets in India: A systematic review of food consumption projection studies. Global Food Security, 23, 182190. https://doi.org/10.1016/j.gfs.2019.05.006

Ali, J., Kapoor, S., \& Moorthy, J. (2010). Buying behaviour of consumers for food products in an emerging economy. British Food Journal, 112(2), 109-124. https://doi.org/10.1108/00070701011018806

Aurino, E., Morrow, V. (2018). "Food prices were high, and the dal became watery". Mixed-method evidence on household food insecurity and children's diets in India. World Development, 111, 211-224. https://doi.org/10.1016/j.worlddev.2018.07.009

Bailey, C., Garg, V., Kapoor, D., Wasser, H., Prabhakaran, D., \& Jaacks, L. M. (2018). Food choice drivers in the context of the nutrition transition in Delhi, India. Journal of Nutrition Education and Behavior, 50(7), 675-686. https://doi.org/10.1016/j. jneb.2018.03.013

Berti, P. R., Krasevec, J., FitzGerald, S. (2004). A review of the effectiveness of agriculture interventions in improving nutrition outcomes. Public Health Nutrition, 7(5), 599-609. https://doi. org/10.1079/PHN2003595

Bhaskar, A. V., Nithya, D., Raju, S., \& Bhavani, R. (2017). Establishing integrated agriculture-nutrition programmes to diversify household food and diets in rural India. Food Security, 9(5), 981-999. https://doi.org/10.1007/s12571-017-0721-Z

Bird, F. A., Pradhan, A., Bhavani, R., \& Dangour, A. D. (2019). Interventions in agriculture for nutrition outcomes: A systematic review focused on South Asia. Food Policy, 82, 39-49. https:// doi.org/10.1016/j.foodpol.2018.10.015

Birdi, T. J., Shah, S. U. (2016). Implementing perennial kitchen garden model to improve diet diversity in Melghat, India. Global Journal of Health Science, 8(4), 10. https://doi.org/10.5539/gjhs. v8n $4 \mathrm{p} 10$

Chakravarty, I. (2000). Food-based strategies to control vitamin A deficiency. Food and Nutrition Bulletin, 21(2), 135-143. https:// doi.org/10.1177/156482650002100205

Chatterjee, S., Kapur, D. (2017). Six puzzles in indian agriculture. Paper presented at the India Policy Forum 2016.

Chaturvedi, S., Ramji, S., Arora, N., Rewal, S., Dasgupta, R., \& Deshmukh, V. (2016). Time-constrained mother and expanding market: emerging model of under-nutrition in India. BMC Public Health, 16(1), 632. https://doi.org/10.1186/s12889-016-3189-4

Chittora, N., Bisht, V., Johar, V. (2017). Marketing and production of fruits and vegetables in India. International Journal of Current Microbiology and Applied Sciences, 6, 2896-2907. https://doi. org/10.20546/ijcmas.2017.609.356

Choudhary, S. (2014). Rising market of convenience food in India. ACADEMICIA: An International Multidisciplinary Research Journal, 4(12), 28-33.

Choudhury, S., Shankar, B., Aleksandrowicz, L., Tak, M., Green, R., Harris, F., Dangour, A. (2018). Global Food Security.

Dangour, A. D., Hawkesworth, S., Shankar, B., Watson, L., Srinivasan, C. S., Morgan, E. H., Haddad, L., \& Waage, J. (2013). Can nutrition be promoted through agriculture-led food price policies? A systematic review. BMJ open, 3(6), e002937. https:// doi.org/10.1136/bmjopen-2013-002937

Dasi, T., Selvaraj, K., Pullakhandam, R., \& Kulkarni, B. (2019). Animal source foods for the alleviation of double burden of malnutrition in countries undergoing nutrition transition. Animal Frontiers, 9(4), 32-38. https://doi.org/10.1093/af/vfz031

Department of Animal Husbandry, D. F. (2017). National Action Plan for Egg \& Poultry-2022. Ministry of Agriculture \& Farmers Welfare, Government of India.

Devi, S. M., Balachandar, V., Lee, S. I., Kim, I. H. (2014). An outline of meat consumption in the Indian population-A pilot review. Korean Journal for Food Science of Animal Resources, 34(4), 507. https://doi.org/10.5851/kosfa.2014.34.4.507

Dhir, B., Singla, N. (2019). Consumption Pattern and Health Implications of Convenience Foods: A Practical Review. Current Journal of Applied Science and Technology, 1-9. https://doi. org/10.9734/cjast/2019/v38i630455

Dubé, L., McRae, C., Wu, Y-H., Ghosh, S., Allen, S., Ross, D., Ray, S., Joshi, P. K., Dermott, J., Jha, S., \& Moore, S. (2020). Impact of the eKutir ICT-enabled social enterprise and its distributed microentrepreneur strategy on fruit and vegetable consumption: A quasi-experimental study in rural and urban communities in Odisha, India. Food Policy, 90, 101787. https://doi.org/10.1016/j. foodpol.2019.101787

Dubey, J., Patel, R. P. (2004). Small wonders of the Indian market. Journal of Consumer Behaviour: an International Research Review, 4(2), 145-151. https://doi.org/10.1002/cb.165

Gaiha, R., Kulkarni, V. S., Pandey, M. K., and Imai, K. S. (2012). On hunger and child mortality in India. Journal of Asian and African studies, 47(1), 3-17. https://doi.org/10.1177/0021909611427015

Gardas, B. B., Raut, R. D., \& Narkhede, B. (2018). Evaluating critical causal factors for post-harvest losses (PHL) in the fruit and vegetables supply chain in India using the DEMATEL approach. Journal of Cleaner Production, 199, 47-61. https://doi. org/10.1016/j.jclepro.2018.07.153

Gavaravarapu, S. M. (2019). Nutrition communication-Rhetoric \& reality. The Indian Journal of Medical Research, 149(3), 333. https://doi.org/10.4103/ijmr.IJMR_1772_18

Gillespie, S., Harris, J., Kadiyala, S. 2012. The agriculturenutrition disconnect in India: what do we know? IFPRI Discussion Paper 1187. Washington, DC: International Food Policy Research Institute.

Girard, A. W., Self, J. L., McAuliffe, C., \& Olude, O. (2012). The effects of household food production strategies on the health and nutrition outcomes of women and young children: a systematic review. Paediatric and Perinatal Epidemiology, 26, 205-222. https://doi.org/10.1111/j.1365-3016.2012.01282.x

Government of Chattisgarh. (2019). Retrieved from https:// 
agriportal.cg.nic.in/agridept/AgriHi/

Gunasekaran, S., Vikkraman, P. (2016). A Study on Branding of Eggs in Select Areas of Tamilnadu. Asian Journal of Research in Social Sciences and Humanities, 6(7), 1870-1882. https://doi. org/10.5958/2249-7315.2016.00550.5

Gupta, V., Downs, S. M., Ghosh-Jerath, S., Lock, K., \& Singh, A. (2016). Unhealthy fat in street and snack foods in low-socioeconomic settings in India: a case study of the food environments of rural villages and an urban slum. Journal of Nutrition Education and Behavior, 48(4), 269-279. e261. https://doi.org/10.1016/j. jneb.2015.11.006

High Level Panel of Experts on Food Security and Nutrition. (2017). Food Systems. A Report by the High Level Panel of Experts on Food Security and Nutrition of the Committee on World Food Security, 152.

Indian Council of Agriculture Research-Indian Agricultural Research Institute. (2017). Krishikosh a Digital Repository of NARES. National Agricultural Innovation Project (NAIP). Retrieved from https://krishikosh.egranth.ac.in/

International Institute of Population Sciences. (2017). National Family Health Survey (NFHS-4), 2015-16.

Jha, S. K., Pinsonneault, A., Dubé, L. (2016). The evolution of an ICT platform-enabled ecosystem for poverty alleviation: The case of eKutir. MIS Quarterly, 40(2), 431-445.

Kadiyala, S., Harris, J., Headey, D., Yosef, S., and Gillespie, S. (2014). Agriculture and nutrition in India: mapping evidence to pathways. Annals of the New York Academy of Sciences, 1331(1), 43-56. https://doi.org/10.1111/nyas.12477

Kehoe, S. H., Dhurde, V., Bhaise, S., Kale, R., Kumaran, K., Gelli, A., Rengalakshmi, R., Lawrence, W., Bloom, I., Sahariah, S. A., Potdar, R. D., Fall, C. H. D. (2019). Barriers and facilitators to fruit and vegetable consumption among rural Indian women of reproductive age. Food and Nutrition Bulletin, 40(1), 87-98. https://doi.org/10.1177/0379572118816459

Kesavan, P., \& Swaminathan, M. S. (2012). Evergreen Revolution in Agriculture: Pathway to a Green Economy: Westville Publishing House.

Khandelwal, S., Verma, G., Shaikh, N. I., Siegel, K. R., Soni, D., Soni, D., Thow, A.-M. (2019). Mapping of policies related to fruits and vegetables accessibility in India. Journal of Hunger \& Environmental Nutrition, 1-17. https://doi.org/10.1080/1932024 8.2019.1595254

Krishna, D., Kumbhare, N., Prabhakar, I., Swetha, B., \& Ashoka, N. (2019). Innovations in Market-Led Extension. International Journal of Current Microbiology and Applied Sciences, 8(2), 3256-3263. https://doi.org/10.20546/ijcmas.2019.802.380

Krishna, V. V., Qaim, M. (2008). Consumer attitudes toward GM food and pesticide residues in India. Review of Agricultural Economics, 30(2), 233-251.

Larson, D. W., Jones, E., Pannu, R., \& Sheokand, R. (2004). Instability in Indian agriculture-a challenge to the green revolution technology. Food Policy, 29(3), 257-273. https://doi. org/10.1016/j.foodpol.2004.05.001

Leroy, J. L., Olney, D. K., \& Ruel, M. (2016). Evaluating nutritionsensitive programs: challenges, methods, and opportunities. Achieving a nutrition revolution for Africa: the road to healthier diets and optimal nutrition. Washington (DC): International Food Policy Research Institute, 130-146. http://doi. org/10.2499/9780896295933_1

Maheshwar, C., Chanakwa, T. (2006). Postharvest losses due to gaps in cold chain in India-a solution. Paper presented at the IV International Conference on Managing Quality in Chains-The
Integrated View on Fruits and Vegetables Quality 712.

Masset, E., Haddad, L., Cornelius, A., \& Isaza-Castro, J. (2012). Effectiveness of agricultural interventions that aim to improve nutritional status of children: systematic review. British Medical Journal, 344, d8222. https://doi.org/10.1136/bmj.d8222

Meenakshi, J. (2016). Trends and patterns in the triple burden of malnutrition in India. Agricultural Economics, 47(S1), 115-134. https://doi.org/10.1111/agec.12304

Miller, V., Yusuf, S., Chow, C. K., Dehghan, M., Corsi, D. J., Lock, K., Popkin, B., Rangarajan, S., Khatib, R., Lear, S. A., Mony, P., Kaur, M., Mohan, V., Vijayakumar, K., Gupta, R., Kruger, A., Tsolekile, L., Mohammadifard, N., Rahman, O., Rosengren, A., Avezum, A., Orlandini, A., Ismail, N., Lopez-Jaramillo, P., Yusufali, A., Karsidag, K., Iqbal, R., Chifamba, J., Oakley, S.M., Ariffin, F., Zatonska, K., Poirier, P., Wei, L., Jian, B., Hui, C., Xu, L., Xiulin, B., Teo, K., \& Mente, A. (2016). Availability, affordability, and consumption of fruits and vegetables in 18 countries across income levels: findings from the Prospective Urban Rural Epidemiology (PURE) study. The Lancet Global Health, 4(10), e695-e703. https://doi.org/10.1016/S2214-109X(16)30186-3

Ministry of Agriculture \& Farmers' Welfare. (2018). Horticulture Statistics at a Glance-2018. Department of Agriculture, Cooperation \& Farmers' Welfare, Horticulture Statistics Division, Government of India.

Ministry of Health and Family Welfare( MoHFW) (2019). Comprehensive National Nutrition Survey (CNNS) National Report. , G. o. I., UNICEF and Population Council. New Delhi.

Minocha, S., Makkar, S., Swaminathan, S., Thomas, T., Webb, P., \& Kurpad, A. V. (2019). Supply and demand of high quality protein foods in India: Trends and opportunities. Global Food Security, 23, 139-148. https://doi.org/10.1016/j.gfs.2019.05.004

Morris, S. S., Beesabathuni, K., \& Headey, D. (2018). An egg for everyone: Pathways to universal access to one of nature's most nutritious foods. Maternal \& Child Nutrition, 14, e12679. https://doi.org/10.1111/mcn.12679

Murthy, D. S., Gajanana, T., Sudha, M., \& Dakshinamoorthy, V. (2009). Marketing and post-harvest losses in fruits: its implications on availability and economy. Indian Journal of Agricultural Economics, 64(902-2016-67302). https://doi. org/10.22004/ag.econ.204629

Murty, P., Rao, M. V., \& Bamji, M. S. (2016). Impact of enriching the diet of women and children through health and nutrition education, introduction of homestead gardens and backyard poultry in rural India. Agricultural Research, 5(2), 210-217. https://doi.org/10.1007/s40003-016-0206-x

Murty P. V. V. S., Vishnuvardhan Ra, M. S. B., \& Prasad V. L. K. (2013). Promotion of Backyard Poultry for Augmenting Egg Consumption in Rural Households. Indian Journal of Nutrition and Dietetics, 50, 150-155.

Nandakumar, T., Gulati, A., Sharma, P., \& Ganguly, K., (2010). Food and nutrition security status in India: opportunities for investment partnerships. Report to ADB-FAOIFAD, Manila.

Narayanan, S. (2019). Food Security From Free Collection of Foods Evidence From India. Available at SSRN 3489102.

National Dairy Development Board. (2017). Per capita availability of Milk by States. Retrieved from https://www.nddb.coop/

National Dairy Development Board. (2019). Compendium of Documents on Dairy Development and Animal Husbandry Schemes being implemented by different departments of Government of India.

National Horticulture Board. (2012). Annual Report. Ministry of Agriculture \& Farmers Welfare, Government of India. Retrieved 
from http://nhb.gov.in/PDFViwer.aspx?enc=3ZOO8K5CzcdC/ Yq6HcdIxMvJ0RY/w0FTznMeREnr5ok=

National Institute of Nutrition. (2010). Dietary Guidelines for Indians.

National Nutrition Monitoring Bureau. (2012). Third Repeat Rural Survey,. Technical Report, 26.

Negi, S., and Anand, N. (2015). Cold chain: a weak link in the fruits and vegetables supply chain in India. IUP Journal of Supply Chain Management, 12(1), 48.

Negi, S., Anand, N. (2016a). Factors leading to losses and wastage in the supply chain of fruits and vegetables sector in India. Paper presented at the Energy Infrastructure and Transportation Challenges and Way Forward-Conference Proceedings International Conference on Management of Infrastructure (pp. I 89-I 105). UPES, Dehradun.

Negi, S., Anand, N. (2016b). An overview of fruits and vegetables' retail supply chain models in India. In Handbook of research on strategic supply chain management in the retail industry (pp. 170187): IGI Global.

Nithya, D., \& Bhavani, R. (2018). Dietary diversity and its relationship with nutritional status among adolescents and adults in rural India. Journal of Biosocial Science, 50(3), 397-413. https://doi. org/10.1017/S0021932017000463

NITI Aayog. (2016). Evaluation study on role of public distribution system in shaping household and nutritional security India. Policy, 72, 80.

NITI Aayog. (2019). Transforming Nutrition in India:Poshan Abhiyaan, a progress report. Retrieved from https://niti.gov.in/ sites/default/files/2020-02/ Poshan__Abhiyaan _2nd_Report. pdf

Ohlan, R. (2016). Dairy economy of India: Structural changes in consumption and production. South Asia Research, 36(2), 241260. https://doi.org/10.1177/0262728016638731

Panda, A., Samal, P. (2016). Poultry production in India: opportunities and challenges ahead. Empowering farm women through livestock and poultry intervention, 50 .

Pandey, V. L., Dev, S. M., \& Jayachandran, U. (2016). Impact of agricultural interventions on the nutritional status in South Asia: A review. Food Policy, 62, 28-40. https://doi.org/10.1016/j. foodpol.2016.05.002

Parasar, R., Bhavani, R. (2016). Review of Agri-Food Value Chain Interventions Aimed at Enhancing Consumption of Nutritious Food by the Poor: India.

Pendse, M., Patil, G. (2016). A study on emerging opportunities in Indian convenience food markets. KHOJ: Journal of Indian Management Research and Practices, 220-223.

Pingali, P., Khwaja, Y., \& Meijer, M. (2005). Commercializing small farms: Reducing transaction cost. Agricultural and Development Economics Division of the Food and Agriculture Organization of the United Nations (FAO - ESA).

Pingali, P., Sunder, N. (2017). Transitioning toward nutritionsensitive food systems in developing countries. Annual Review of Resource Economics, 9, 439-459. https://doi.org/10.1146/ annurev-resource-100516-053552

Poonam, A., Saha, S., Nayak, P. K., Sathpaty, B. S., Shahid, M., Nayak, A. K., Tripathy, R., Jambhulkar, N.N., Kumar, G. A. K., Mondal, B., Sahu, P.K., Giri, S. C., Nedunchezhian, M., Kumar, U., \& Lenka, S. K. (2018). Integrated Rice-based Farming Systems for Enhancing Climate Resilience and Profitability in Eastern India. In Rice Research for Enhancing Productivity, Profitability and Climate Resilience. Odisha, India. ICAR-National Rice Research Institute.
Pradhan, A., Sathanandhan, R., Panda, A. K., Wagh, R. (2018). Improving household diet diversity through promotion of nutrition gardens in India. American Journal of Food Science and Nutrition, 5, 43-51.

Pries, A. M., Filteau, S., Ferguson, E. L. (2019). Snack food and beverage consumption and young child nutrition in low-and middle-income countries: A systematic review. Maternal \& Child Nutrition, 15, e12729. https://doi.org/10.1111/mcn.12729

Raghunathan, K., Headey, D., Herforth, A. Affordability of nutritious diets in rural India. IFPRI Discussion Paper 1912. Washington, DC: International Food Policy Research Institute (IFPRI). 2020.

Rais, M., Kaul, A., Jain, A. (2019). Evaluation of Public Private Partnerships in Perishable Food Supply Chain in India. Journal of Supply Chain Management Systems, 8(2).

Rampal, P. (2018). An analysis of protein consumption in India through plant and animal sources. Food and Nutrition Bulletin, 39(4), 564-580. https://doi.org/10.1177/0379572118810104

Rani, V., Arends, D. E., Brouwer, I. D. (2010). Dietary diversity as an indicator of micronutrient adequacy of the diet of five to eight year old Indian rural children. Nutrition and Food Science, 40(5), 466-476. https://doi.org/10.1108/00346651011076974

Ruel, M. T., Quisumbing, A. R., Balagamwala, M. (2018). Nutritionsensitive agriculture: What have we learned so far?. Global Food Security, 17, 128-153. https://doi.org/10.1016/j.gfs.2018.01.002

Rukmani, R., Gopinath, R., Anuradha, G., Sanjeev, R., Yadav, V. K. (2019). Women as Drivers of Change for Nutrition-Sensitive Agriculture: Case Study of a Novel Extension Approach in Wardha, India. Agricultural Research, 8(4), 523-530. https://doi. org/10.1007/s40003-018-0383-x

Sachdeva, S., Sachdev, T. R., Sachdeva, R. (2013). Increasing fruit and vegetable consumption: challenges and opportunities. Indian journal of community medicine: official publication of Indian Association of Preventive \& Social Medicine, 38(4), 192. https:// doi.org/10.4103/0970-0218.120146

Saran, S., Sasidhar, P., Singh, R., \& Sastry, K. (2005). Indian poultry industry: current scenario and future prospects: a review. Indian Journal of Animal Sciences (India).

Sekhar, C.S., Roy, D., \& Bhatt, Y. Food Inflation and Food Price Volatility in India: Trends and Determinants. New Delhi: 2017.

Shankar, B., Poole, N., \& Bird, F. A. (2019). Agricultural inputs and nutrition in South Asia. Food Policy, 82, 28-38. https://doi. org/10.1016/j.foodpol.2018.10.011

Shetty, P. S. (2002). Nutrition transition in India. Public Health Nutrition, 5(1a), 175-182. https://doi.org/10.1079/PHN2001291

Srivastava, S., Balaji, S., \& Kolady, D. (2016). Is there a Convergence in Dietary Energy Intake among Expenditure-Classes in India? Agricultural Economics Research Review, 29, 119-128. https:// doi.org/10.22004/ag.econ.253172

Surendran, S., Selvaraj, K., Turner, C., Addanki, S., Kannuri, N. K., Debbarma, A., Kadiyala, S., Kinra, S., Walls, H. (2020). Characterising the fruit and vegetable environment of periurban Hyderabad, India. Global Food Security, 24, 100343. https://doi.org/10.1016/j.gfs.2019.100343

Tak, M., Shankar, B., Kadiyala, S. (2019). Dietary Transition in India: Temporal and Regional Trends, 1993 to 2012. Food and Nutrition Bulletin, 40(2), 254-270. https://doi. org/10.1177/0379572119833856

Thow, A. M., Kadiyala, S., Khandelwal, S., Menon, P., Downs, S., Reddy, K. S. (2016). Toward food policy for the dual burden of malnutrition: an exploratory policy space analysis in India. Food and Nutrition Bulletin, 37(3), 261-274. https://doi. org/10.1177/0379572116653863 
Umali-Deininger, D., \& Sur, M. (2007). Food safety in a globalizing world: opportunities and challenges for India. Agricultural Economics, 37, 135-147.https://doi.org/10.22004/ag.econ.25746 Sangeetha, V., Satyapriya, P. S., Lenin, V. Paul, S., Barua, S., Muralikrishnan, L., \& Sitaram. (2018). An Agri-Nutri (A2N) Smart Village Model for Food and Nutrition Security. Division of Agricultural Extension, ICAR-Indian Agricultural Research Institute, New Delhi- 110 012. Retrieved from https://www.iari. res.in/files/AgriNutriSmart_23032018.pdf

van den Bold, M., Kohli, N., Gillespie, S., Zuberi, S., Rajeesh, S., \&
Chakraborty, B. (2015). Is there an enabling environment for nutrition-sensitive agriculture in South Asia? Stakeholder perspectives from India, Bangladesh, and Pakistan. Food and Nutrition Bulletin, 36(2), 231-247. http://doi. org/10.1177/0379572115587494

Vijayaraghavan, K., Nayak, M. U., Bamji, M. S., Ramana, G., \& Reddy, V. (1997). Home gardening for combating vitamin A deficiency in rural India. Food and Nutrition Bulletin, 18(4), 1-7. https:// doi.org/10.1177/156482659701800403

WHO. (2017). WHO. Double-duty actions. Policy brief. Geneva. 